\title{
KPIM OF GAS TRANSPORTATION: ROBUST MODIFICATION OF GAS PIPELINE EQUATIONS
}

\author{
A. Falade ${ }^{1}$, A.F. Olaberinjo ${ }^{2}$, M.O. Oyewola ${ }^{3}$, \\ F.U. Babalola ${ }^{4}$ and S.M. Adaramola ${ }^{5}$ \\ ${ }^{1}$ Department of Petroleum and Gas Engineering, \\ University of Lagos, NIGERIA \\ ${ }^{2}$ Petroleo Brasileiro Nigeria Limited, Lagos, NIGERIA \\ ${ }^{3}$ Discipline of Mechanical Engineering \\ School of Engineering, The University of Newcastle, \\ NSW, 2308, AUSTRALIA \\ ${ }^{4}$ Department of Chemical Engineering, \\ University of Lagos, Lagos, NIGERIA \\ ${ }^{5}$ Division of Environmental Engineering, \\ University of Saskatchewan, Saskatoon, CANADA
}

\begin{abstract}
Studies of the flow conditions of natural gases in pipelines have led to the development of complex equations for relating the volume transmitted through a gas pipeline to the various factors involved, thus deciding the optimum pressures and pipeline dimensions to be used. From equations of this type, various combinations of pipe diameter and wall thickness for a desired rate of gas throughput can be calculated. This research work presents modified forms of the basic gas flow equation for horizontal flow developed by Weymouth and the basic gas flow equation for inclined flow developed by Ferguson. The modified equations incorporate noniterative forms of the Colebrook-White friction factor into the original forms of the Weymouth's and Ferguson's equations. These modified equations thus eliminate the need for iteration in predicting the flow rate of gas through pipelines as is the case with their original forms when the Colebrook-White friction factor is used. The modified equations also have a wider range of application since the Colebrook-White friction factor is valid for turbulent gas flow as well as for gas flow in a transition zone. On comparing the results it can be seen that the modified Ferguson's equation gives a more accurate prediction of gas flow rates because it takes the pipeline elevation into account. Lower deviations from measured gas flow rates were observed with the modified Ferguson's equation than with the modified basic gas flow equation. The deviations observed using the modified Ferguson equation were found to range from $-0.16 \%$ to $+3.21 \%$. Conclusively, these less cumbersome newly developed equations with high degree reliability will be useful in predicting the rates of gas flow for a wide range of its conditions, pipeline elevation and pipeline lengths.
\end{abstract}

\section{NOMENCLATURE}
$D=$ pipeline diameter, $\mathrm{L}$, in.;
$e^{\prime}=$ absolute roughness, $\mathrm{L}$, in.;
$f=$ Darcy-Weisbach or Moody friction factor, dimensionless;
$g=$ gravitational acceleration, $\mathrm{L} / \mathrm{T}^{2}, \mathrm{ft} / \mathrm{s}^{2}$; 


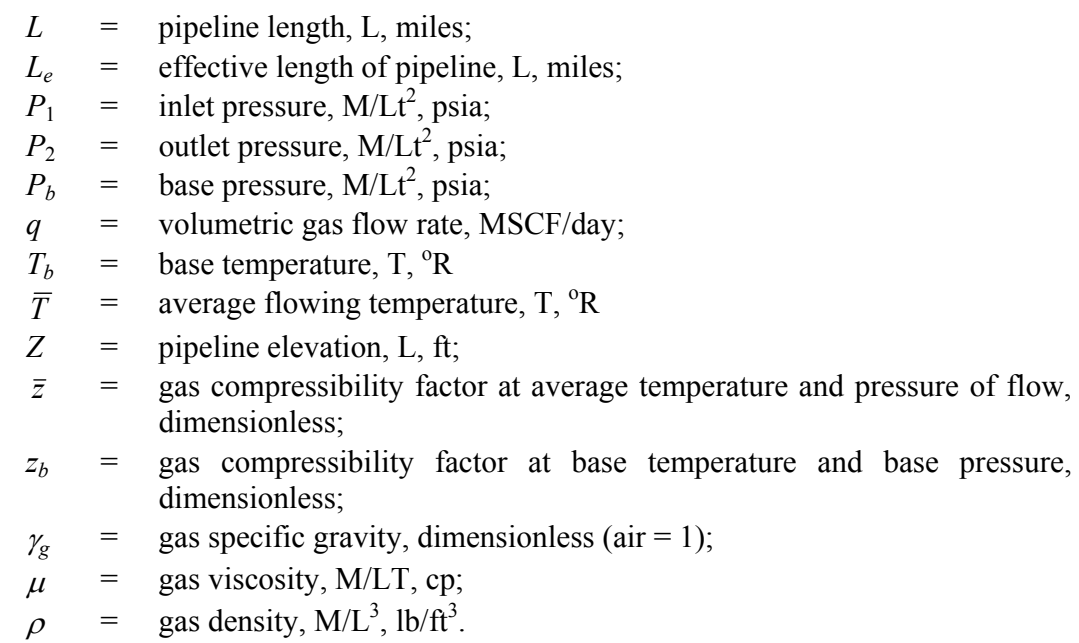

\section{S.I. METRIC CONVERSION FACTORS}

$\begin{array}{ll}\mathrm{ft} \times 3.048 \mathrm{E}-01 & =\mathrm{m} \\ \left({ }^{\circ} \mathrm{F}-32\right) / 1.8 & ={ }^{\circ} \mathrm{C} \\ \text { Cuft } \times 2.831 \mathrm{E}-02 & =\mathrm{m}^{3} \\ \text { mile } \times 1.609344 \mathrm{E}+00 & =\mathrm{km} \\ \mathrm{psi} \times 6.894757 \mathrm{E}+00 & =\mathrm{kPa} \\ \text { in } \times 2.54 \mathrm{E}+00 & =\mathrm{cm} \\ \mathrm{cp} \times 1.0 \mathrm{E}+00 & =\mathrm{mPa} . \mathrm{s}\end{array}$

\section{INTRODUCTION}

Natural gas is one of the most important sources of energy in the world. It refers to naturally occurring hydrocarbons which are found in gaseous form, mostly in sedimentary rocks beneath the earth's surface. Natural gas is usually composed largely of methane and other compounds belonging to the alkane series such as ethane as well as impurities.

Transmission of gas over long distances is usually achieved by means of pipeline systems, which remain to be the most economical method of transporting fluids (gases included). Over the years, studies of the flow conditions of natural gases in pipelines have led to the development of various flow equations. The equations of the kind that are now available were all obtained by solving the energy equation under different sets of assumptions.

The most fundamental of these gas flow equations is the general gas flow equation (developed by Thomas R. Weymouth in 1912), which is one of the most widely used formulas in the industry for calculating the flow of natural gas through pipelines at high pressures. It forms the basis for most of the widely used equations in the natural gas industry. However, the limitation of the general gas flow equation is the difficulty associated with determining the friction factor in this equation.

With time, various correlations have been developed for determining the friction factor. One of the most accurate of these correlations has been found to be the Colebrook-White friction factor correlation [1]. The limitation of this correlation, however, is that it is iterative in nature, since the friction factor appears on both sides of the equation. It is as a result of this difficulty that various other 
friction factor correlations have been developed, some of which are approximations of the Colebrook-White friction factor. Thus, the Weymouth, Panhandle A and Panhandle B equations are some of the gas flow equations that were all developed by substituting these other approximate friction factor correlations into the general gas flow equation.

In this work, a non-iterative form of the Colebrook-White friction factor correlation was developed and incorporated into the original general gas flow equation and the Ferguson equations to arrive at the modified general gas flow equation and the modified Ferguson equation, respectively.

\section{MATHEMATICAL CONSIDERATIONS}

The form of the Reynolds number used in the natural gas industry is given as

$$
R_{N}=\frac{711 P_{b} q \gamma_{g}}{T_{b} D \mu z_{b}} .
$$

The general gas flow equation developed by Weymouth is given as

$$
q=0.07752 \frac{T_{b}}{P_{b}}\left[\frac{\left(P_{1}^{2}-P_{2}^{2}\right) D^{5}}{\gamma_{g} \bar{T} L f \bar{z}}\right]^{0.5} .
$$

The Colebrook-White friction factor correlation is given as

$$
\frac{1}{\sqrt{f}}=-2 \log \left[\frac{e^{\prime}}{3.7065 D}+\frac{2.51}{R_{N} \sqrt{f}}\right] \text {. }
$$

On combining Eqs. $(1,2)$ and (3), it can be seen that

$$
\frac{1}{\sqrt{f}}=-2 \log \left(\frac{e^{\prime}}{3.7065 D}+\frac{0.045541}{B}\right),
$$

where the term $B$ is defined as

$$
B=\left[\frac{\left(P_{1}^{2}-P_{2}^{2}\right) D^{3} \gamma_{g}}{\bar{T} L \bar{z} \mu^{2}}\right]^{0.5}
$$

Equation (4) is a non-iterative form of the Colebrook-White friction factor which can be used only with the general gas flow equation.

On incorporating the non-iterative form of the Colebrook-White friction factor into the general gas flow equation, the modified general gas flow equation is given as

$$
\therefore q=0.15504 \times \frac{T_{b}}{P_{b}} \times \frac{B \mu D}{\gamma_{g}} \log \left(\frac{e^{\prime}}{3.7065 D}+\frac{0.045541}{B}\right)^{-1} .
$$


Equation (6) is the modified general gas flow equation. However, the limitation of the modified general gas flow equation is the fact that its use is restricted only to horizontal pipes without inclination or elevation, since the original general gas flow equation from which it is derived assumes that the pipeline elevation is negligible. This limitation was expressly observed when the modified general gas flow equation was tested with three sets of field data to predict gas flow rates. The field data used were obtained from the work of Tian and Adewunmi [2]. The field tests were conducted with a wide range of gas flow conditions as well as different pipe sizes, lengths and elevations. Figures 1, 2 and 3 show the graphical comparison of the actual measured gas flow rates with the predicted gas flow rates using the modified general gas flow equation for each of the three sets of data, respectively. The deviations of the predicted gas flow rates from measured gas flow rates using the modified general gas flow equation were found to range from $-24.55 \%$ to $+9.48 \%$. The reason for such a high degree of deviations from the measured values

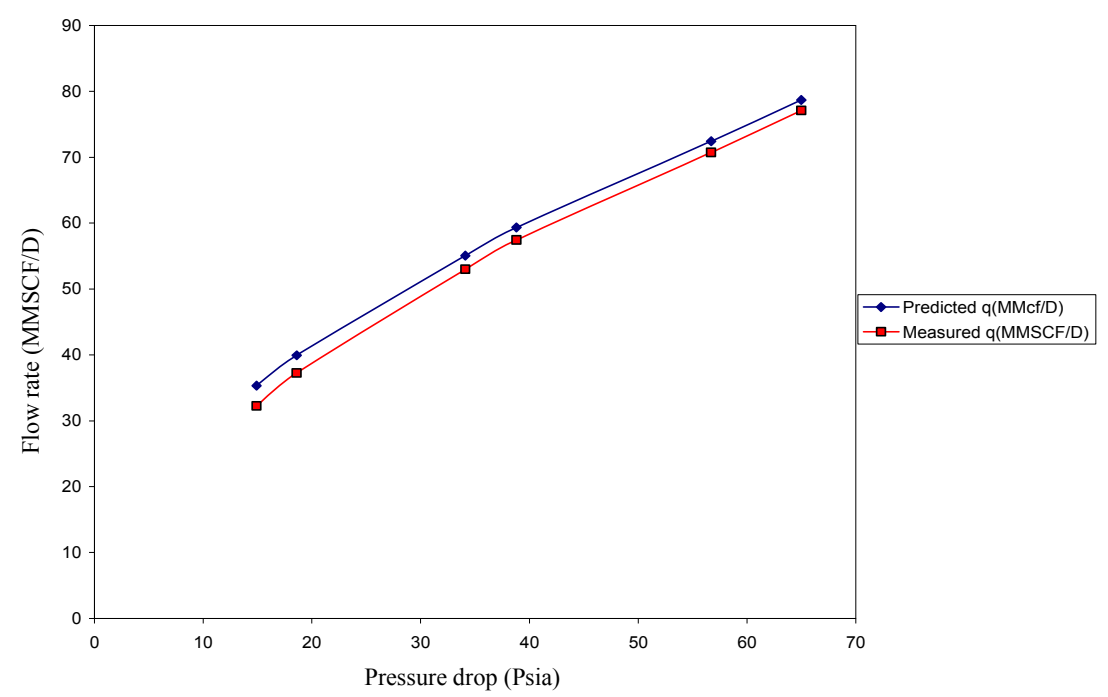

Fig. 1. Graphical comparison of measured gas flow rates with predicted gas flow rates using the modified general gas flow equation (the $1^{\text {st }}$ data set).

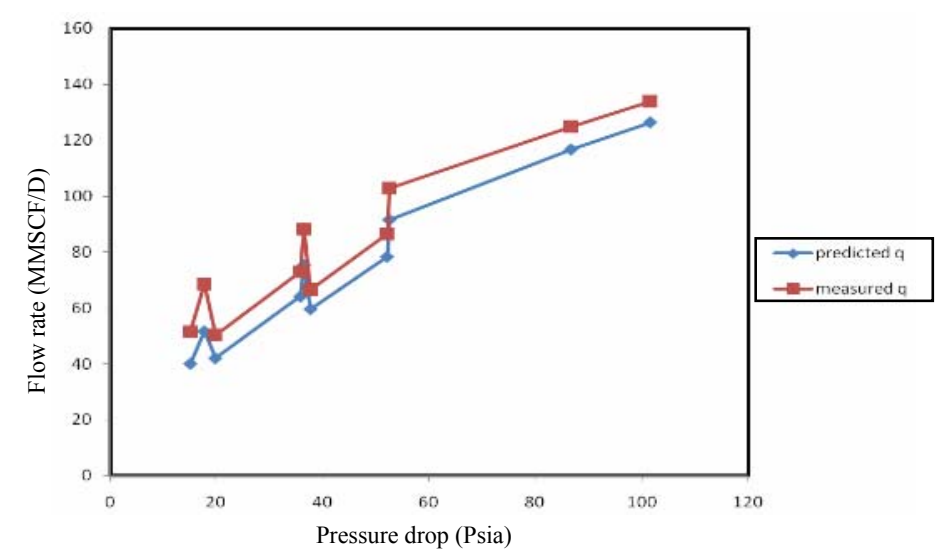

Fig. 2. Graphical comparison of measured gas flow rates with predicted gas flow rates using the modified general gas flow equation (the $2^{\text {nd }}$ data set). 


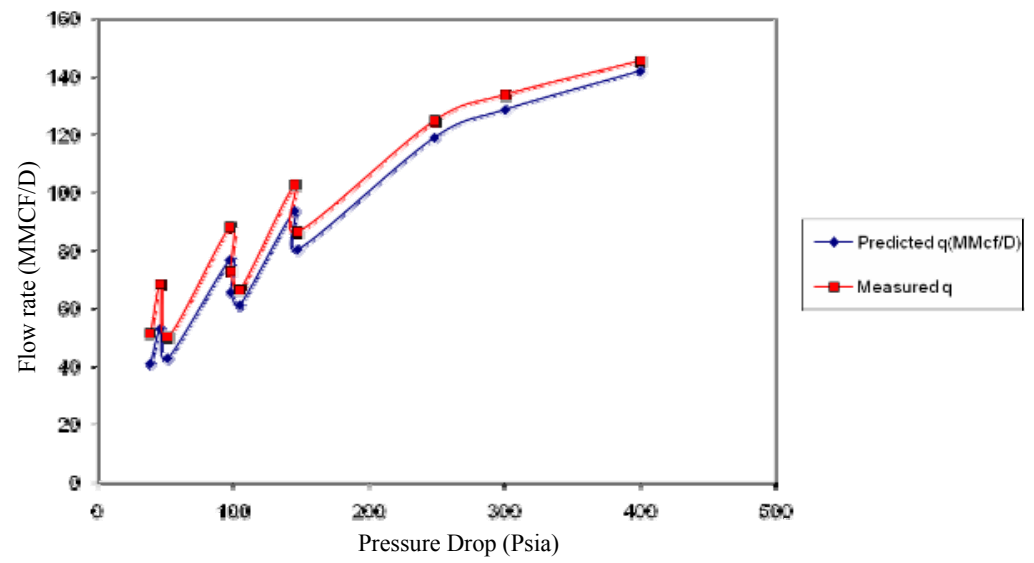

Fig. 3. Graphical comparison of measured gas flow rates with predicted gas flow rates using the modified general gas flow equation (the 3rd data set).

was investigated and found to be a result of the fact that the pipeline elevation term was neglected in arriving at the original form of the general gas flow equation.

In view of the above, another form of the general gas flow equation, which accounts for the pipeline elevation and inclination (otherwise known as the Ferguson equation), was considered as a better candidate for modification. This equation, however, has the same limitation of requiring several iterations when the Colebrook-White friction factor is used with it. Therefore, a modified form of the Ferguson equation was also developed.

The Ferguson equation is given as

$$
q=0.07752 \frac{T_{b}}{P_{b}}\left[\frac{\left(P_{1}^{2}-e^{S} P_{2}^{2}\right) D^{5}}{\gamma_{g} \bar{T} L_{e} \bar{z}}\right]^{0.5} \times \frac{1}{\sqrt{f}},
$$

where

$$
L_{e}=\left(\frac{e^{S}-1}{S}\right) \times L ; \quad S=\frac{0.0375 \times \gamma_{g} \times \Delta Z}{\bar{T} \times \bar{z}} ;
$$

$\Delta Z$ - outlet elevation of pipeline minus inlet elevation of pipeline;

$e \quad-$ base of natural logarithm $=2.718$.

On combining Eqs. $(1,2)$ and $(7)$, the Colebrook-White friction factor becomes:

$$
\frac{1}{\sqrt{f}}=-2 \log \left(\frac{e^{\prime}}{3.7065 D}+\frac{0.045541}{C}\right),
$$

where the term $C$ is defined as

$$
C=\left[\frac{\left(P_{1}^{2}-e^{S} P_{2}^{2}\right) D^{3} \gamma_{g}}{\bar{T} L_{e} \bar{z} \mu^{2}}\right]^{0.5} .
$$


Equation (8) is a non-iterative form of the Colebrook-White friction factor equation that can be used with only the Ferguson equation since it was derived from the Reynolds number and the Ferguson equation.

On incorporating the non-iterative form of the Colebrook-White friction factor into the Ferguson equation, the modified Ferguson equation is obtained as

$$
\therefore q=0.15504 \times \frac{T_{b}}{P_{b}} \times \frac{C \mu D}{\gamma_{g}} \log \left(\frac{e^{\prime}}{3.7065 D}+\frac{0.045541}{C}\right)^{-1} \text {. }
$$

The modified Ferguson equation was also tested with the same sets of data that were used to test the modified general gas flow equation. It was found to predict the gas flow rates more accurately than the modified general gas flow equation.

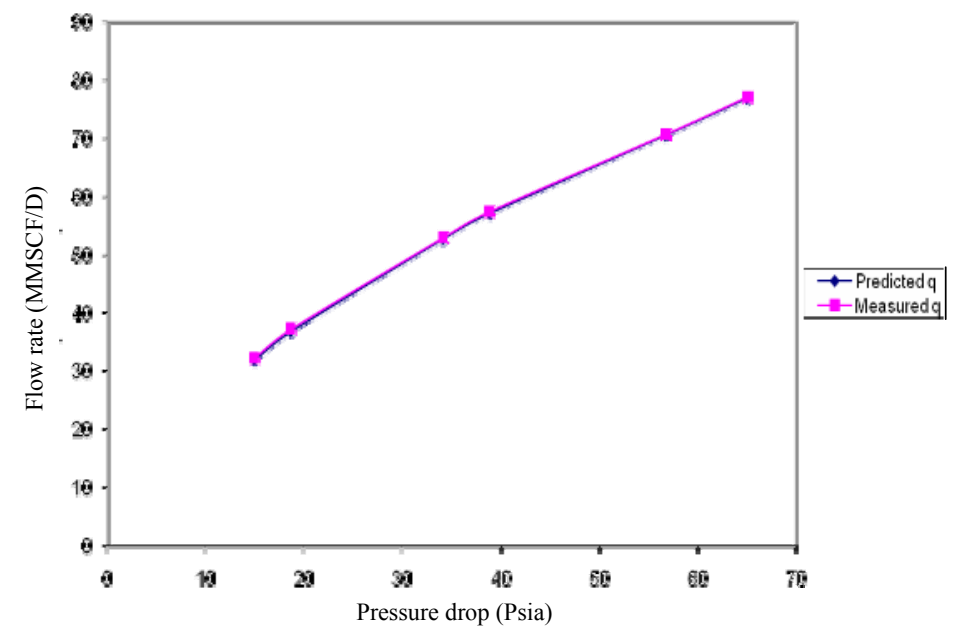

Fig. 4. Graphical comparison of measured gas flow rates with predicted gas flow rates using the modified Ferguson equation (the $1^{\text {st }}$ data set).

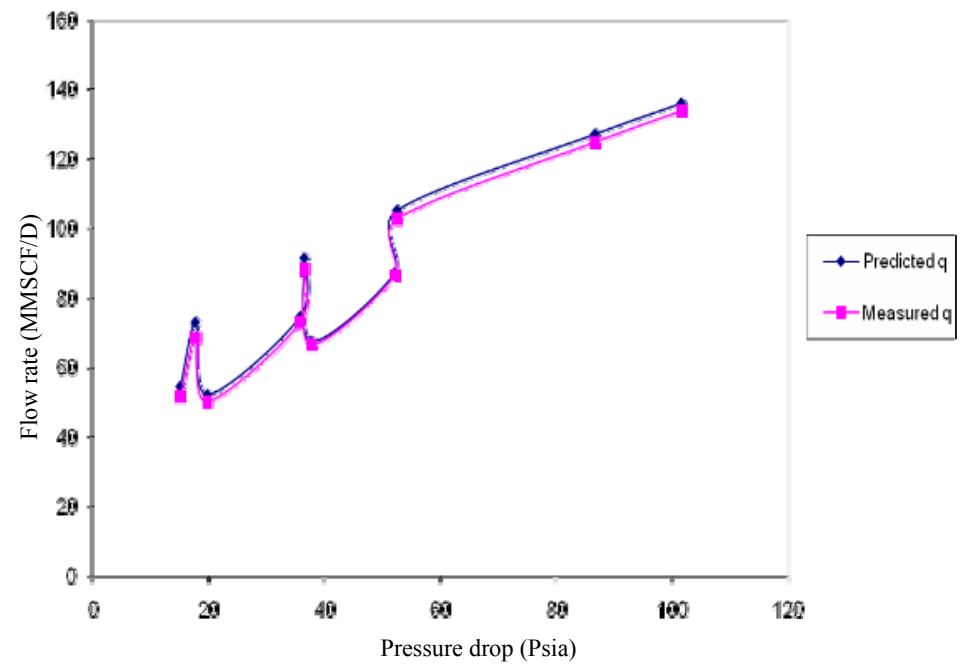

Fig. 5. Graphical comparison of measured gas flow rates with predicted gas flow rates using the modified Ferguson equation (the $2^{\text {nd }}$ data set). 


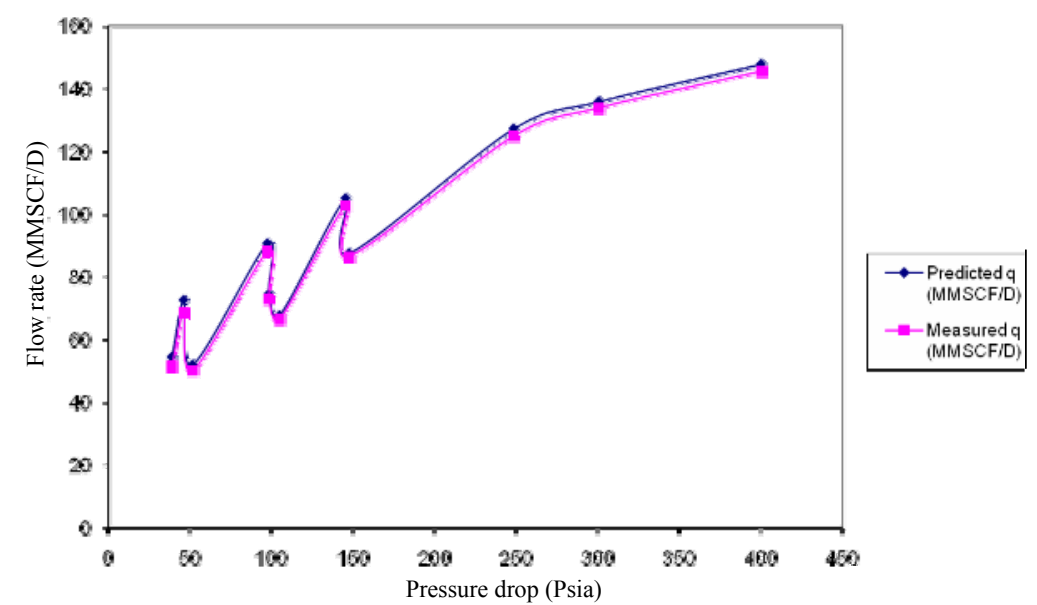

Fig. 6. Graphical comparison of measured gas flow rates with predicted gas flow rates using the modified Ferguson equation (the $3^{\text {rd }}$ data set).

The deviations of predicted gas flow rates from actual measured values were found to range from $-1.53 \%$ to $6.55 \%$. The improved accuracy can be attributed to the fact that the modified Ferguson equation takes the pipeline elevation into account unlike the modified general gas flow equation, which does not. The graphical comparison of the actual measured gas flow rates with the predicted gas flow rates using the modified Ferguson equation for each of the three sets of data are shown in Figs. 4, 5 and 6, respectively.

\section{VALIDATION AND DISCUSSION OF THE RESULTS}

The results obtained by using the modified Ferguson equation to predict gas flow rates were compared with those obtained employing two of the popular gas pipeline equations: the Panhandle A and Panhandle B equations using the same sets of field test data from the work of Tian and Adewunmi [2]. For each set of the data used, the same gas composition and gas flow conditions applied to the modified Ferguson equation as well as the Panhandle A and Panhandle B equations.

The Panhandle A and B equations were chosen for this comparison because the field data available were readily applicable to both of them. Also, these two equations are the most widely used for the design of gas pipelines employed in the long-distance transmission of gas. The comparison of the results obtained using these three equations to predict gas flow rate with three sets of field data is shown graphically in Fig. 7, 8 and 9.

From the results obtained above, it can be said that the modified Ferguson equation gives a more accurate prediction of the gas flow rate than the modified general gas flow equation. There were over 25 different gas flow conditions in which the modified Ferguson equation was used for prediction of gas flow rates with the highest deviation from the measured gas flow rate being $6.55 \%$.

From Figs. 7, 8 and 9, it can be seen that the modified Ferguson equation gives more accurate predictions of the gas flow rate than the Panhandle A and B equations. The modified Ferguson equation also has the lowest range of deviations from measured values which range from $-1.53 \%$ to $6.55 \%$ for all the flow situations considered. The Panhandle A equation has deviations which range from 
$-17.04 \%$ to $23.37 \%$, while the Panhandle B equation - those ranging from $-1.34 \%$ to $31.94 \%$.

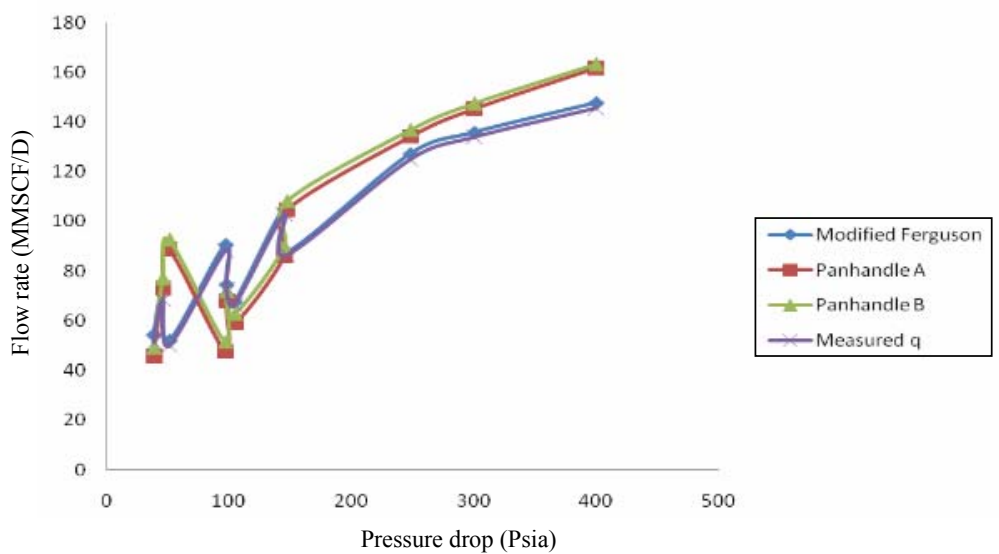

Fig. 7. Comparison of measured flow rate with predicted flow rate using the modified Ferguson equation, the Panhandle A equation and the Panhandle B equation (the $1^{\text {st }}$ data set).

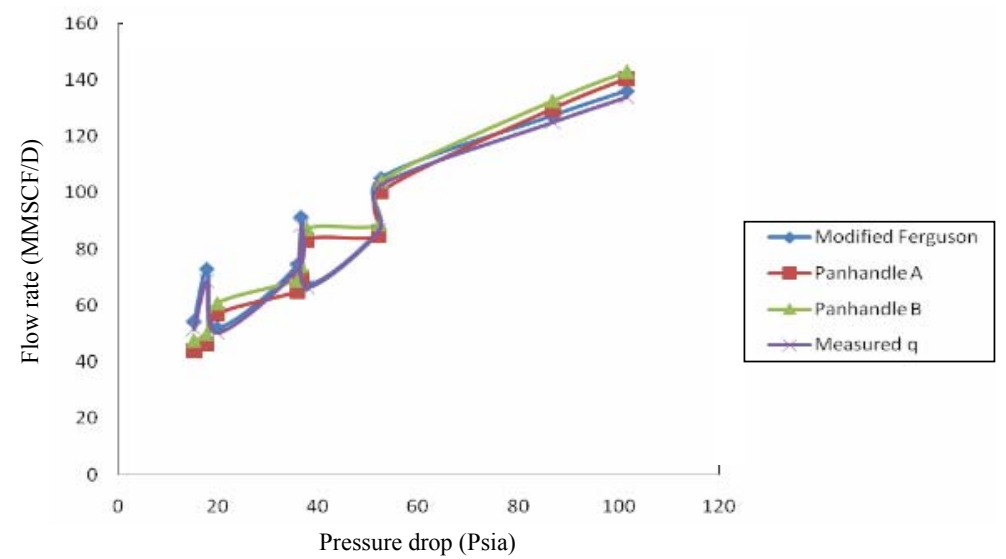

Fig. 8. Comparison of measured flow rate with predicted flow rate using the modified Ferguson equation, the Panhandle A equation and the Panhandle B equation (the $2^{\text {nd }}$ data set).

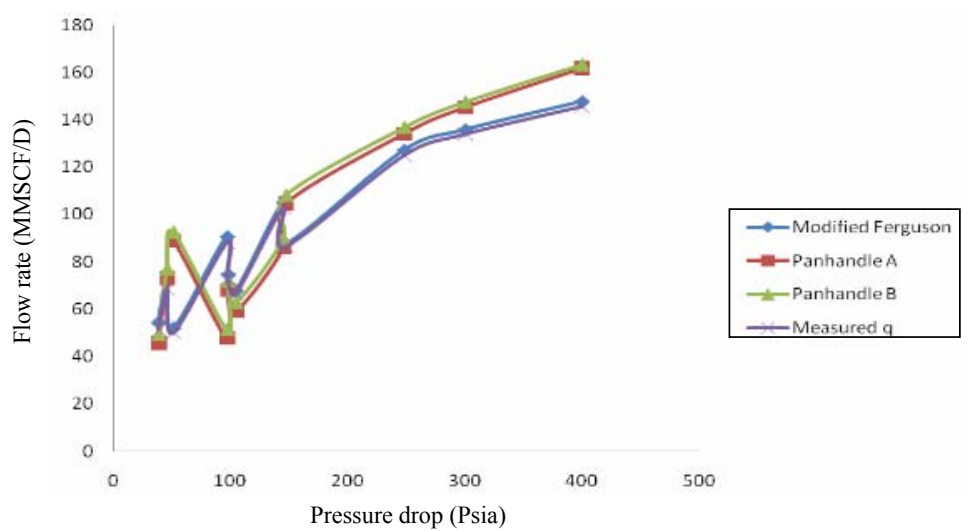

Fig. 9. Comparison of measured flow rate with predicted flow rate using the modified Ferguson equation, the Panhandle A equation and the Panhandle B equation (the 3rd data set). 
Also, from Figs. 7, 8 and 9 it can be seen that the plots of the predicted flow rates obtained by using the modified Ferguson equation were found to follow a trend similar to that of the actual measured flow rate. These plots were also found to be very close to the actual measured values.

\title{
4. CONCLUSIONS
}

The modified Ferguson equation is recommended for the use in the natural gas industry for the prediction of gas flow rates for the following reasons:

1. It is non-iterative, so the gas flow rate can be directly calculated without iterating.

2. It requires less computation, and so it is time-saving.

3. It predicts gas flow rates that have low deviations from the actual measured gas flow rates.

4. It has a wider range of application since the Colebrook-White equation from which it is derived applies to a wider range of turbulent gas flow conditions than the Weymouth, Panhandle A and Panhandle B equations.

\section{REFERENCES}

1. Bilgesu, H.I., \& Koperna, Jr., G.J. (1996). The Impact of Friction Factor on the Pressure Loss Prediction in Gas pipelines. Society of Petroleum Engineers, Paper 309996, (Sept.).

2. Tian, S. \& Adewumi, M.A. (1994). Development of Analytical Design Equation for Gas Pipelines. Society of Petroleum Engineers Production \& Facilities (May), pp. 104-105.

\section{GĀZES TRANPORTĒŠANA: MODIFICĒTIE GĀZES PĀRVADĪŠANAS VIENĀDOJUMI}

\author{
A. Falade, A.F. Olaberinjo, M.O. Oyewola, \\ F.U. Babalola and S.M. Adaramola
}

Kopsavilkums

Pētījumi par gāzes plūsmu gāzes vadā noved pie kompleksiem vienādojumiem, ietverot daudzus faktorus, kas ļauj risināt gāzes vada spiediena un dimensiju optimizāciju. Ar šāda tipa vienādojumiem var aprēḳināt vada diametru un tā sieniņu biezumu dažādās kombinācijās. Šie pētījumi veido Weymonth izstrādātā un Fergusona attīstītā bāzu vienādojumu modifikācijas. Šì vienādojuma tālākā pilnveidošana veidota Colebrok-White formā. Apskatîto modificēto Fergusona vienādojuma deviācija sastāda no $-0,16 \%$ līdz $+3,2 \%$.

Šajā pētījumā iegūti vienkāršāki vienādojumi ar augstāku ticamību, kurus varēs lietderīgi izmantot gāzes plūsmu aprēḳināšanai plašā apstākḷu daudzveidībā gāzes vada griezumā un garumā.

05.08.2008. 